\title{
Colorimetric sensing of anions by a neutral biphenyl based amide receptor
}

\author{
Ana M. Costero* and Sergio Peransi \\ Dpto. Química Orgánica. Universidad de Valencia. Doctor Moliner,50. 46100-Burjassot. \\ Valencia. Spain \\ E-mail: Ana.Costero@uv.es
}

Dedicated to Professor Joan Bosch, on the occasion of his 60th birthday

\begin{abstract}
A new colorimetric sensor for fluoride is described. Compound 1 shows an open structure and its behaviour is compared with that of two related closed compounds $\mathbf{2}$ and $\mathbf{3}$. In all cases, the red colour developed in the presence of fluoride can be related to deprotonation processes, however ligand 1 gives rise to a faster colour change than $\mathbf{2}$ or $\mathbf{3}$ because of its higher flexibility. Other halides as well as carboxylates have been studied and the stoichiometry and complexation constants for the corresponding ligands have been determined.
\end{abstract}

Keywords: Colorimetric sensing, anions, amides

\section{Introduction}

Construction of colorimetric sensors for specific anions is a particularly attractive research area. This type of sensor can be built following the binding site-signaling unit approach by attaching an appropriate photoactive group to a specific anion receptor. ${ }^{1}$ Many of the ligands designed for anion recognition are based on amide ${ }^{2}$ groups as binding site in the sensor, even though other functional groups such as urea, thiourea or their amido derivatives have also received attention especially for recognizing carboxylate. ${ }^{3}$

Our research group has been working on the preparation of sensors containing substituted biphenyl moieties able to act as signaling unit and pyridine amide derivatives as anion receptors. ${ }^{4}$ The sensors previously described were cyclic systems where the cavity size determines the complexation capacity (Figure 1). For this reason the new related open compound 1 has been prepared in order to study its complexation ability for halides and several carboxylates. 
<smiles>COC(=O)c1cc([N+](=O)[O-])ccc1-c1ccc([N+](=O)[O-])cc1C(=O)OCCOCCNC(=O)c1cccc(C(=O)NNCCOCCO)c1</smiles><smiles>O=C(NCCOCCO)c1cccc(C(=O)NCCOC(=O)c2cc([N+](=O)[O-])ccc2-c2ccc([N+](=O)[O-])cc2C(=O)[O-])n1</smiles><smiles>O=C(NCCOCCO)c1cccc(C(=O)NCCOCCOCCOCCO)n1</smiles>

\section{Figure 1}

\section{Results and Discussion}

Ligand 1 was easily prepared as shown in Scheme 1. The anhydride of the 4,4'-dinitro-2,2'diphenic acid was transformed in the corresponding monomethyl ester by reaction with methanol. This compound was converted into the corresponding acyl chloride by treatment with thionyl chloride. ${ }^{5}$ Diamide 1 was obtained after reaction with compound 4 . $^{6}$

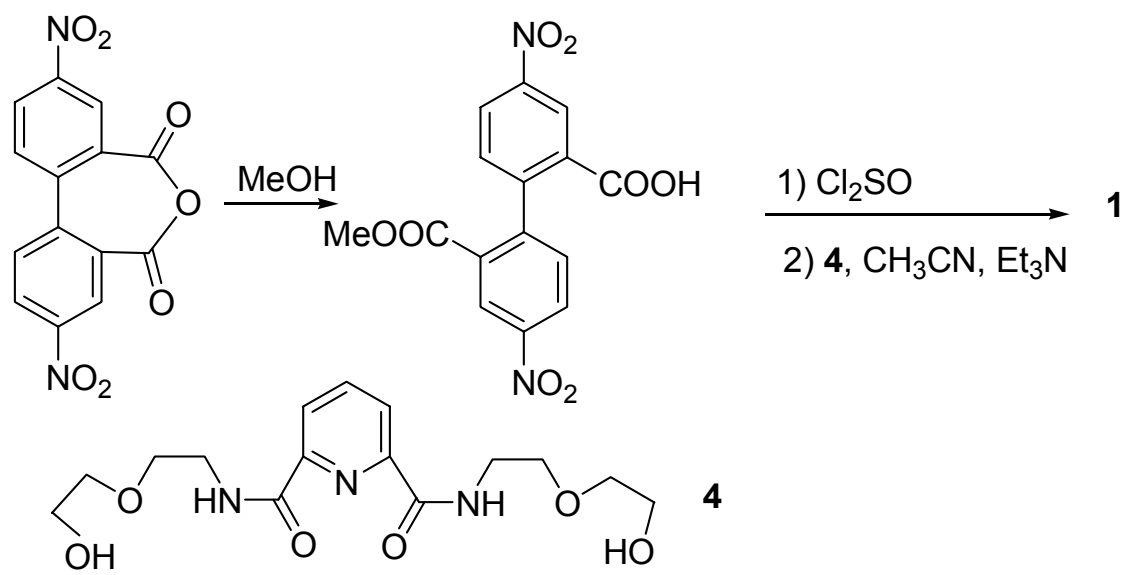

\section{Scheme 1}


Colorimetric recognition of $\mathrm{F}^{-}$has been a topic of interest during the last years and there are many systems able to act as sensors for this anion. ${ }^{7}$ The sensing mechanism for most of these systems is a deprotonation reaction due to the strong basicity of the fluoride anion in organic solvents. ${ }^{8}$ Taking into account that ligand $\mathbf{1}$ contains two amido groups in its structure, we decided to explore its ability in anion complexation and sensing. Firstly, the complexation studies were carried out with TBAF in both acetonitrile and DMSO. Thus, the addition of 5 equiv. of this salts to the ligand solution gives rise to an instantaneously and strong change in the colour of the solution from yellow to dark red $(\lambda=476 \mathrm{~nm}$, Figure 2$)$.

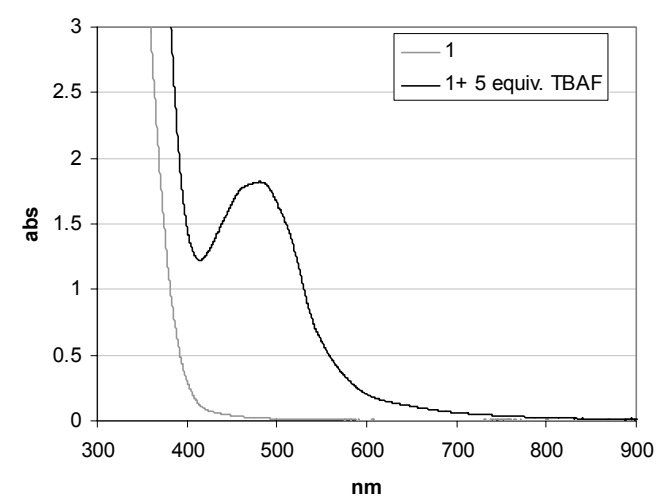

Figure 2. UV spectra of ligand $1\left(2.79 \times 10^{-3} \mathrm{M}\right.$ in acetonitrile) and ligand $\mathbf{1}\left(2.79 \times 10^{-3} \mathrm{M}\right.$ in acetonitrile) +5 equiv. of TBAF at $25^{\circ} \mathrm{C}$.

This colour change should be produced by the corresponding deprotonation reaction as was previously described for ligands 2 and 3 . ${ }^{4}$ However, whereas with these two ligands the deprotonation reaction was very slow ( $36 \mathrm{~h}$. to a naked-eye detection), ligand $\mathbf{1}$ develops the colour immediately after fluoride addition. This kinetic difference seems to be related to the larger flexibility of ligand $\mathbf{1}$ that allows the anion to access easily the amide hydrogens. In addition, the sensitivity of ligand $1(0.001 \mathrm{M})$ was studied both under naked eye and UV conditions and it was of $1.5 \mathrm{mM}$ and $100 \mu \mathrm{M}$ respectively. These values agree with those obtained with ligands $\mathbf{2}$ and $\mathbf{3}$ but whereas ligand $\mathbf{1}$ gives the response at room temperature, 2 and 3 need higher temperatures to develop the red colour. The detection limit observed with ligand $\mathbf{1}$ is in accordance with the results showed by some chromogenic or fluorogenic $\mathrm{F}^{-}$ chemosensors described in the literature. ${ }^{9}$

Additional complexation studies were carried out with $\mathrm{Br}^{-}, \mathrm{I}^{-}$(both as their tetrabutylammonium salts) also in acetonitrile and by the addition of 5 equiv. of the corresponding anion, but no colour was developed in any case (Figure 3). 


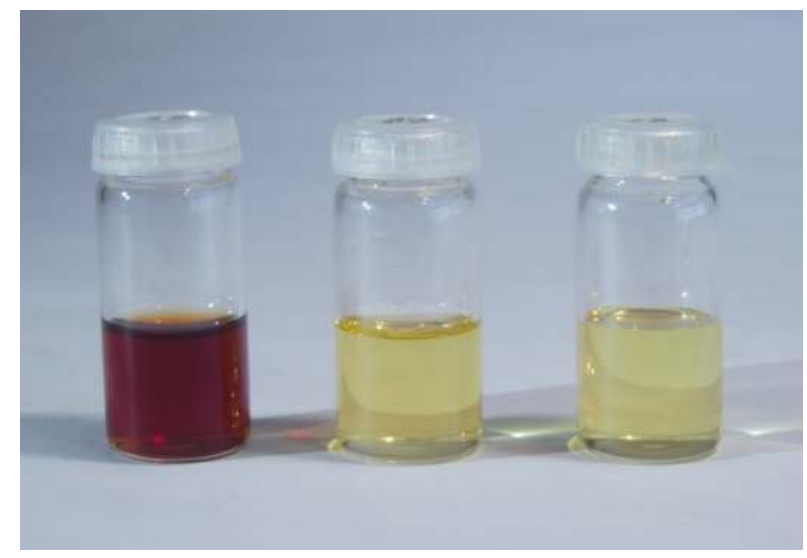

Figure 3. (from left to right) ligand $\mathbf{1}+\mathrm{TBAF}$ ( 5 equiv.), ligand $\mathbf{1}+\mathrm{TBABr}$ ( 5 equiv.), free ligand 1 (the solvent was DMSO)

Proton NMR experiments were performed in order to assess the affinity of receptor $\mathbf{1}$ for the studied anions. As can be seen in Figure 4, after the addition of the anions clear differences were observed in the NMR spectra. Thus, complexation with $\mathrm{Br}^{-}, \mathrm{I}^{-}$, as their tetrabutylammonium salts induce clear changes in the biphenyl system making both aromatic rings more different than they are in the free ligand. The strongest influence is exerted on $\mathrm{H}_{\mathrm{B}}$, and $\mathrm{H}_{\mathrm{C}}$ '. As it was expected, also strong shifts were observed for the NH signals (Table 1). On the other hand, a clear symmetry was observed in the formed complexes where both biphenyl systems are almost equivalent.

However, a different behaviour was observed in the presence of TBAF because the NMR spectrum shows that several different species are immediately generated in the solution. One of these species, the main one, seems to be the deprotonated system similar to these observed with ligands 2 and 3. This suggestion agrees with the following observations: (a) the red colour developed in the solution, (b) the absence of the HN signals in the ${ }^{1} \mathrm{H}$ NMR spectrum (c) the signal at $146.85 \mathrm{ppm}$ corresponding to the $\mathrm{F}_{2} \mathrm{H}^{-}$species that appears in the ${ }^{19} \mathrm{~F}$ NMR spectrum. In addition to the deprotonated ligand, different species generated through hydrolysis process, are present in the solution. These types of species are similar to those observed when TBAOH was added to the ligand under the same conditions.

Complexation with different carboxylates $\left(\mathrm{CH}_{3} \mathrm{COO}^{-}, \mathrm{C}_{6} \mathrm{H}_{5} \mathrm{COO}^{-}, 4-\mathrm{NO}_{2} \mathrm{C}_{6} \mathrm{H}_{4} \mathrm{COO}^{-}\right.$and 4$\mathrm{CH}_{3} \mathrm{OC}_{6} \mathrm{H}_{4} \mathrm{COO}^{-}$, all of them as their tetrabutylammonium salts) has also been explored. The modifications observed with these anions in the ${ }^{1} \mathrm{H}$ NMR spectra were similar to those induced by TBABr and TBAI (Table 1). 

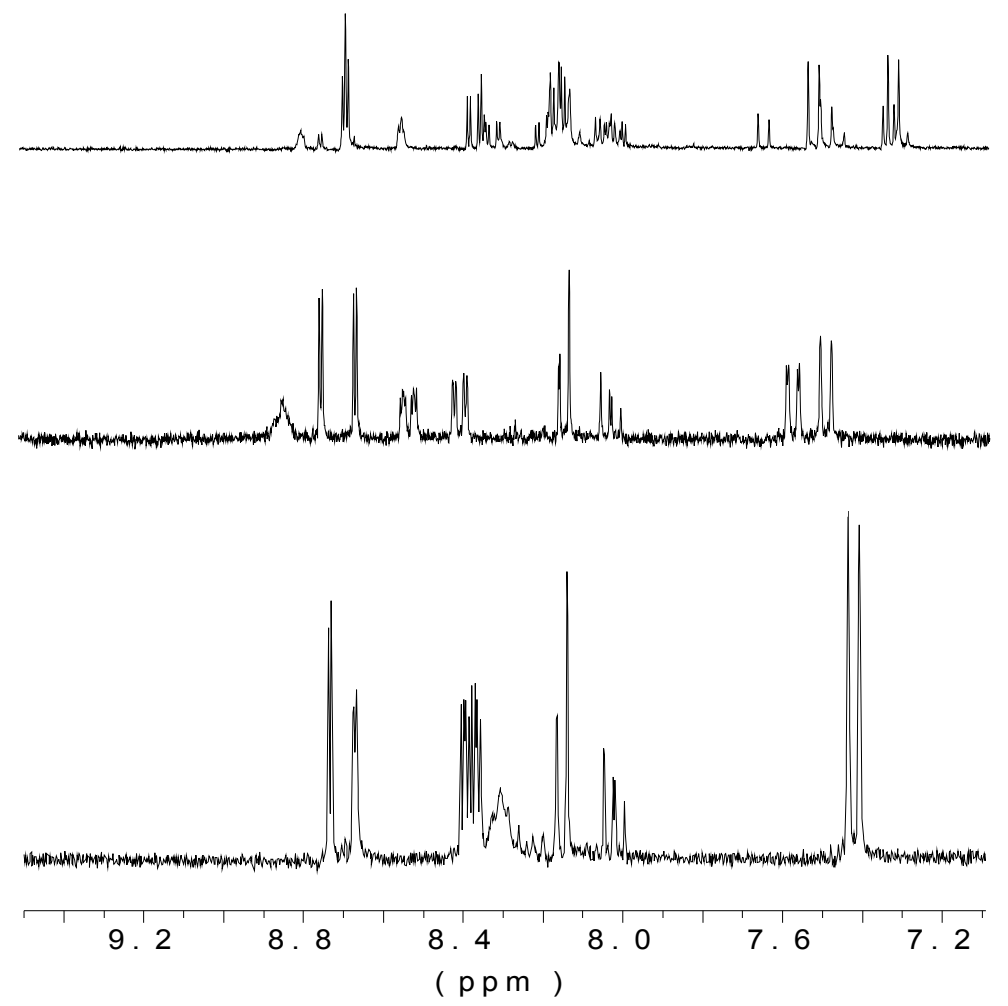

Figure 4. Aromatic zone of ${ }^{1} \mathrm{H}$ NMR spectrum in $\mathrm{CD}_{3} \mathrm{CN}$ of (from bottom to top): free ligand $\mathbf{1}$, ligand $1+\operatorname{TBABr}(5$ equiv), ligand $\mathbf{1}+\mathrm{TBAF}$ ( 5 equiv).

Table 1. Shifts of the aromatic hydrogens of ligand $\mathbf{1}$ and ligand $\mathbf{1}$ in the presence of different TBA salts

\begin{tabular}{|c|c|c|c|c|c|c|c|c|c|c|}
\hline & $\begin{array}{l}\delta\left(\mathrm{H}_{\mathrm{A}}\right) \\
\delta\left(\mathrm{H}_{\mathrm{A}}\right)\end{array}$ & $\Delta \delta$ & $\begin{array}{l}\delta\left(\mathrm{H}_{\mathrm{B}}\right) \\
\delta\left(\mathrm{H}_{\mathrm{B}^{\prime}}\right)\end{array}$ & $\Delta \delta$ & $\begin{array}{l}\delta\left(\mathrm{H}_{\mathrm{C}}\right) \\
\delta\left(\mathrm{H}_{\mathrm{C}}\right)\end{array}$ & $\Delta \delta$ & $\begin{array}{l}\delta\left(\mathrm{H}_{1}\right. \\
) \\
\delta\left(\mathrm{H}_{2}\right. \\
)\end{array}$ & $\Delta \delta$ & $\delta(\mathrm{NH})$ & $\Delta \delta$ \\
\hline 1 & $\begin{array}{l}8.70 \\
8.64 \\
\end{array}$ & & $\begin{array}{l}8.35 \\
8.34 \\
\end{array}$ & & $\begin{array}{l}7.39 \\
7.39 \\
\end{array}$ & & $\begin{array}{l}8.11 \\
7.98 \\
\end{array}$ & & 8.22 & \\
\hline $\mathbf{1}^{-} \mathrm{TBA}^{+} \mathrm{F}^{-}$ & $\begin{array}{l}8.62 \\
8.63 \\
\end{array}$ & $\begin{array}{l}0.08 \\
0.01 \\
\end{array}$ & $\begin{array}{l}8.29 \\
8.08 \\
\end{array}$ & $\begin{array}{l}0.06 \\
0.26 \\
\end{array}$ & $\begin{array}{l}7.42 \\
7.21 \\
\end{array}$ & $\begin{array}{l}-0.03 \\
0.18 \\
\end{array}$ & $\begin{array}{l}8.06 \\
7.94 \\
\end{array}$ & $\begin{array}{l}0.05 \\
0.04 \\
\end{array}$ & --- & \\
\hline $\mathbf{1}+\mathrm{TBABr}$ & $\begin{array}{l}8.64 \\
8.53 \\
\end{array}$ & $\begin{array}{l}0.06 \\
0.11 \\
\end{array}$ & $\begin{array}{l}8.32 \\
8.55 \\
\end{array}$ & $\begin{array}{l}0.03 \\
-0.20 \\
\end{array}$ & $\begin{array}{l}7.37 \\
7.53 \\
\end{array}$ & $\begin{array}{l}0.02 \\
-0.14 \\
\end{array}$ & $\begin{array}{l}7.97 \\
7.88 \\
\end{array}$ & $\begin{array}{l}0.14 \\
0.10 \\
\end{array}$ & 9.68 & 1.46 \\
\hline $\mathbf{1}+\mathrm{TBAI}$ & $\begin{array}{l}8.69 \\
8.60 \\
\end{array}$ & $\begin{array}{l}0.01 \\
0.04\end{array}$ & $\begin{array}{l}8.33 \\
8.46 \\
\end{array}$ & $\begin{array}{l}0.02 \\
-0.12 \\
\end{array}$ & $\begin{array}{l}7.39 \\
7.48 \\
\end{array}$ & $\begin{array}{l}0 \\
-0.09 \\
\end{array}$ & $\begin{array}{l}8.07 \\
7.94 \\
\end{array}$ & $\begin{array}{l}0.04 \\
0.05 \\
\end{array}$ & 8.79 & 0.57 \\
\hline $\mathbf{1}+\mathrm{TBAAcO}$ & $\begin{array}{l}8.70 \\
8.61 \\
\end{array}$ & $\begin{array}{l}0 \\
0.03 \\
\end{array}$ & $\begin{array}{l}8.32 \\
8.50 \\
\end{array}$ & $\begin{array}{l}0.03 \\
-016 \\
\end{array}$ & $\begin{array}{l}7.39 \\
7.55 \\
\end{array}$ & $\begin{array}{l}0 \\
-0.16 \\
\end{array}$ & $\begin{array}{l}7.96 \\
7.85 \\
\end{array}$ & $\begin{array}{l}0.15 \\
0.13 \\
\end{array}$ & 9.15 & 0.93 \\
\hline $\mathbf{1}+\mathrm{TBAPhCO}_{2}$ & $\begin{array}{l}8.74 \\
8.67\end{array}$ & $\begin{array}{l}-0.04 \\
-0.03\end{array}$ & $\begin{array}{l}8.35 \\
8.45\end{array}$ & $\begin{array}{l}0 \\
-011\end{array}$ & $\begin{array}{l}7.42 \\
7.53\end{array}$ & $\begin{array}{l}-0.02 \\
-0.14\end{array}$ & $\begin{array}{l}8.09 \\
7.95\end{array}$ & $\begin{array}{l}0.02 \\
0.03\end{array}$ & 9.50 & 1.28 \\
\hline
\end{tabular}



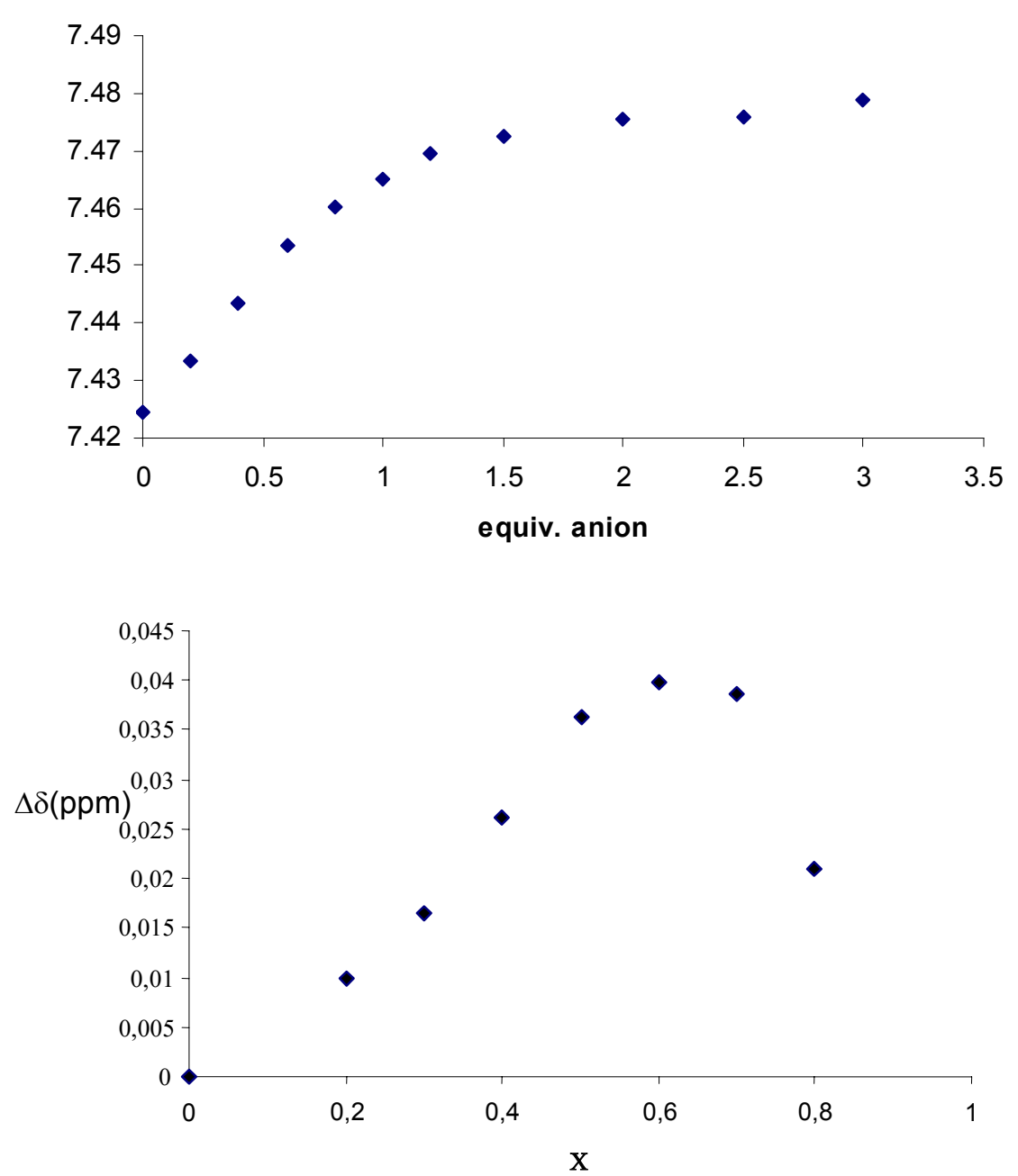

Figure 5. (a) Molar ratio titration by using ${ }^{1} \mathrm{H}$ NMR for ligand 1 and tetrabutylammonium benzoate in $\mathrm{CD}_{3} \mathrm{CN}$, (b) Job plot $\left(\mathrm{X}=\mathrm{X}_{\text {anion }} / \mathrm{X}_{\text {ligand }}\right)$.

Different ${ }^{1} \mathrm{H}$ NMR experiments in $\mathrm{CD}_{3} \mathrm{CN}$ or in $\mathrm{d}_{6}$-DMSO, depending on the solubility of the salts, were carried out in order to determine both stoichiometry and complexation constants. Firstly, the stoichiometry of the complexes was studied by using the molar ratio method. ${ }^{10}$ In this method, varying amounts of anion are added to a constant amount of ligand and the chemical shift value of a determined proton in the ${ }^{1} \mathrm{H}$ NMR spectrum of each solution is measured and plotted against the ration moles ligand/anion. The change of the slope observed around 2 suggested a 1:2 stoichiometry for all the complexes formed (see figure 5a for tetrabutylammonium benzoate; for the other salts see the supplementary material). However in order to confirm the proposed stoichiometries, the method of continuous variations introduced by Job was also used. This method is performed by preparing several solutions consisting of varying amounts of the ligand and anion, with the sum of the anion concentration and ligand 
concentration constant for each solution. Thus, the ${ }^{1} \mathrm{H}$ NMR spectrum of each solution was registered and the chemical shift of a proton was plotted against the mole fraction of the anion (see figure $5 \mathrm{~b}$ for tetrabutylammonium benzoate; for the other salts see the supplementary material). The presence of a maximum around $X=0.66$ confirms the 1:2 stoichiometry. Data obtained in the titration experiments were suitable for determining the corresponding complexation constants. The values were obtaining by using SPECFIT/ $32^{\mathrm{TM}}$ programme ${ }^{11}$ and are listed in Table 2.

Table 2. Complexation constants. for ligand 1 determined by ${ }^{1} \mathrm{H}$ NMR tritiations

\begin{tabular}{|l|l|l|l|l|l|l|}
\hline & $\mathrm{Br}^{-}$ & $\mathrm{I}^{-}$ & $\mathrm{CH}_{3} \mathrm{CO}_{2}^{-}$ & $\begin{array}{l}\mathrm{C}_{6} \mathrm{H}_{5} \mathrm{COO} \\
-\end{array}$ & $\begin{array}{l}4- \\
\mathrm{NO}_{2} \mathrm{C}_{6} \mathrm{H}_{4} \mathrm{COO}^{-}\end{array}$ & $\begin{array}{l}4- \\
\mathrm{CH}_{3} \mathrm{OC}_{6} \mathrm{H}_{4} \mathrm{COO}^{-}\end{array}$ \\
\hline $\begin{array}{l}\text { Solven } \\
\mathrm{t}\end{array}$ & $\mathrm{CD}_{3} \mathrm{CN}$ & $\mathrm{CD}_{3} \mathrm{CN}$ & $\mathrm{CD}_{3} \mathrm{CN}$ & $\mathrm{CD}_{3} \mathrm{CN}$ & $\mathrm{DMSO}_{6}$ & DMSO-d \\
\hline $\log \mathrm{K}$ & $3.6 \pm 0.1$ & $3.3 \pm 0.1$ & $3.2 \pm 0.1$ & $3.4 \pm 0.2$ & $3.4 \pm 0.2$ & $3.4 \pm 0.2$ \\
\hline
\end{tabular}

The 1:2 stoichiometry supposes that each carboxylate forms a hydrogen bond with one $\mathrm{NH}$ group and also interacts with $\mathrm{H}_{\mathrm{B}}$, and $\mathrm{H}_{\mathrm{C}}$, in the ortho position to the nitro group as it was accepted for ligands $\mathbf{2}$ and $\mathbf{3}$ and several other ligands. ${ }^{12}$ (Figure 6).

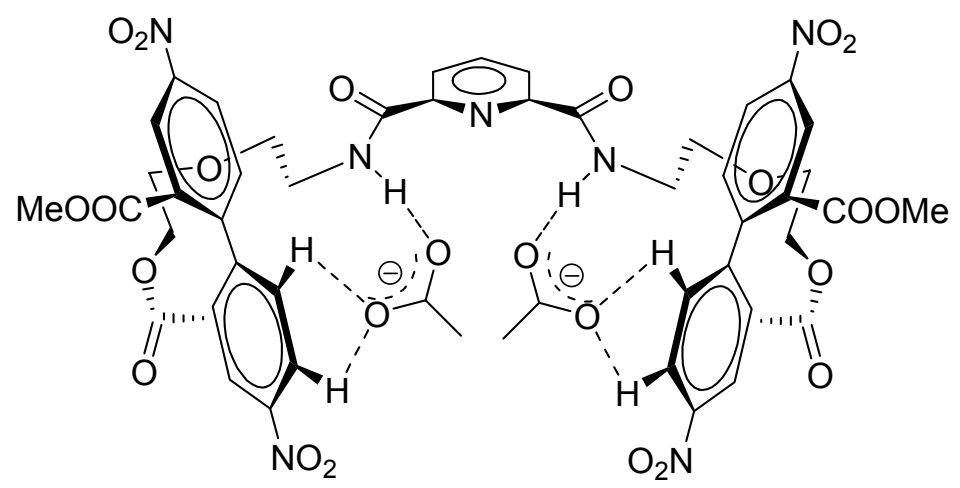

\section{Figure 6}

Complexation constant values are very similar for all the anions studied and are independent of the anion basicity. Thus, similar values were observed for both 4-nitro and 4methoxybenzoate $(3.4 \pm 0.2$ for both anions).

Finally, the influence of the counter ion on the complexation was also studied. Thus, complexation experiments were carried out with acetate both as tetrabutylammonium and ammonium salts using ${ }^{1} \mathrm{H}$ NMR. It was observed that ammonium acetate did not induce any change in the spectrum, which can be related to the lower lipophilic character of the ammonium cation. 


\section{Conclusions}

Ligand $\mathbf{1}$ can be used as a colorimetric $\mathrm{F}^{-}$sensor in a similar way than ligands $\mathbf{2}$ and $\mathbf{3}$ through a deprotonation reaction. However, ligand 1 gives rise to an instantaneous change in colour whereas 2 and 3 require longer times. This quick response should be related to the higher flexibility of ligand $\mathbf{1}$. On the other hand, the other anions studied give rise to the corresponding 1:2 complexes, but no deprotonation was observed. The strong shift of some of the byphenyl aromatic signals observed in the ${ }^{1} \mathrm{H}$ NMR spectra of the complexes suggests some contributions of $\mathrm{C}-\mathrm{H} \cdots$ anion interactions.

\section{Experimental Section}

General Procedures. All commercially available reagents were used without further purification. Water sensitive reactions were performed under argon. Column chromatography was carried out on SDS activated neutral aluminium oxide (0.05-0.2 mm; activity degree 1$)$. IR spectra were recorded on a Perkin-Elmer 1750 FT-IR and a Bruker Equinox 55 FT-IR. NMR spectra were recorded with Bruker Avance 300/500 and Varian Unity-300/400 spectrometers. Chemical shifts are reported in parts per million downfield from TMS. Spectra were referenced to residual undeuterated solvent. High resolution mass spectra were taken with a Fisons VGAUTOSPEC and those using the eletrospray ionizing technique were recorded on an HPLC-MS with ion trap Bruker 3000-Esquire Plus. UV spectra were run at $20^{\circ} \mathrm{C}$ (thermostated) on a Shimadzu UV-2102 PC

Synthesis of N,N'-bis[3-oxa-pentyl-5-(5-nitro-2-(4-nitro-2-methyl benzoate) benzoate)]-2,6pyridine dicarboxamide (1). 2-(2-methyloxycarbonyl-4-nitrophenyl)-5-nitrobenzoic acid $^{5}$ $(0.5050 \mathrm{~g}, 1.46 \mathrm{mmol})$ was added to an excess of thionyl chloride $(30 \mathrm{ml})$. The suspension was refluxed under magnetic stirring until it became a clear solution $(2 \mathrm{~h})$. Then, the excess of thionyl chloride was distilled, dry benzene was added and the solution was re-distilled. The solid obtained was dissolved in dry $\mathrm{CH}_{2} \mathrm{Cl}_{2}(25 \mathrm{ml})$ and added dropwise and under argon atmosphere to a stirred mixture of $4^{6}(0.3000 \mathrm{~g}, 0.88 \mathrm{mmol})$ and dry triethylamine $(99 \%)(0.1797 \mathrm{~g}, 1.76$ $\mathrm{mmol})$ in dry $\mathrm{CH}_{2} \mathrm{Cl}_{2}(20 \mathrm{ml})$, at $0^{\circ} \mathrm{C}$. When the addition was finished, the stirring was continued at a room temperature. After completion of the reaction (TLC, 12 hours) the solution was concentrated under reduced pressure. The crude reaction product was purified by chromatography through a neutral alumina column using $\mathrm{CH}_{2} \mathrm{Cl}_{2}: \mathrm{EtAcO}(6: 4)$ as eluents to give the desired compound as a pale yellow powder $(0.2451 \mathrm{~g}, 0.25 \mathrm{mmol})$. (28\% yield). ${ }^{1} \mathrm{H}-\mathrm{NMR}$ $\left(300 \mathrm{MHz}, \mathrm{CDCl}_{3}\right) \delta_{\mathrm{H}}(\mathrm{ppm}): 8.87(2 \mathrm{H}, \mathrm{d}, \mathrm{J}=2.5 \mathrm{~Hz}, \mathrm{Ar}-\mathrm{H}), 8.84(2 \mathrm{H}, \mathrm{d}, \mathrm{J}=2.3 \mathrm{~Hz}, \mathrm{Ar}-\mathrm{H}), 8.39$ $(4 \mathrm{H}, \mathrm{m}, \mathrm{Ar}-\mathrm{H}), 8.29\left(2 \mathrm{H}_{\mathrm{b}}, \mathrm{d}, \mathrm{J}=7.5 \mathrm{~Hz}, \mathrm{Ar}-\mathrm{H}\right), 8.13(2 \mathrm{H}, \mathrm{bb}, 2-\mathrm{CO}-\mathrm{NH}), 8.00\left(1 \mathrm{H}_{\mathrm{a}}, \mathrm{t}, \mathrm{J}=7.5 \mathrm{~Hz}\right.$, Ar-H), $7.36(2 \mathrm{H}, \mathrm{d}, \mathrm{J}=8.3 \mathrm{~Hz}, \mathrm{Ar}-\mathrm{H}), 7.34(2 \mathrm{H}, \mathrm{d}, \mathrm{J}=8.3 \mathrm{~Hz}, \mathrm{Ar}-\mathrm{H}), 4.28$ (4H, bb, 2Ar-COO- $\mathrm{CH}_{2}-$ ), $3.72\left(6 \mathrm{H}, \mathrm{s}, 2-\mathrm{COOCH}_{3}\right), 3.55\left(12 \mathrm{H}, \mathrm{bb}, 2-\mathrm{NH}-\mathrm{CH}_{2} \mathrm{CH}_{2}-\mathrm{O}-\mathrm{CH}_{2-}\right)$ ). ${ }^{13} \mathrm{C}-\mathrm{NMR}(75 \mathrm{MHz}$, $\left.\mathrm{CDCl}_{3}\right) \delta_{\mathrm{C}}(\mathrm{ppm}): 164.98$ (2-Ar-CO-NH), 164.65 (2-Ar-CO-CH$\left.{ }_{2}^{-}\right), 163.97\left(2-\mathrm{COOCH}_{3}\right), 148.98$ 
$\left(2 \mathrm{C}_{\mathrm{Ar}}\right), 148.37\left(2 \mathrm{C}_{\mathrm{Ar}}\right), 148.20\left(4 \mathrm{C}_{\mathrm{Ar}}\right), 147.69\left(2 \mathrm{C}_{\mathrm{Ar}}\right), 139.32\left(\mathrm{C}_{\mathrm{Ar}}\right), 131.26\left(2 \mathrm{C}_{\mathrm{Ar}}\right), 131.23\left(2 \mathrm{C}_{\mathrm{Ar}}\right)$, $130.45\left(2 \mathrm{C}_{\mathrm{Ar}}\right), 130.34\left(2 \mathrm{C}_{\mathrm{Ar}}\right), 126.88\left(2 \mathrm{C}_{\mathrm{Ar}}\right), 126.79\left(2 \mathrm{C}_{\mathrm{Ar}}\right), 125.74\left(4 \mathrm{C}_{\mathrm{Ar}}\right), 125.35\left(2 \mathrm{C}_{\mathrm{Ar}}\right), 70.01$ (2- $\left.-\mathrm{OCH}_{2} \mathrm{CH}_{2} \mathrm{NHCO}-\right), \quad 68.87 \quad\left(2-\mathrm{COOCH}_{2} \mathrm{CH}_{2} \mathrm{O}-\right)$, $64.82 \quad$ (2- $\left.\mathrm{COOCH}_{2} \mathrm{CH}_{2} \mathrm{O}-\right)$, 39.54 (2$\left.\mathrm{OCH}_{2} \mathrm{CH}_{2} \mathrm{NHCO}-\right), 53.14\left(2-\mathrm{COOCH}_{3}\right)$. IR $(\mathrm{KBr}) v_{\max }\left(\mathrm{cm}^{-1}\right)$ : $3391(\mathrm{~N}-\mathrm{H}), 3094(\mathrm{Ar}-\mathrm{H}), 1731$ ($\left.\left.(\mathrm{C}=\mathrm{O})-\mathrm{OCH}_{3}\right), 1634(-(\mathrm{C}=\mathrm{O})-\mathrm{N}-\mathrm{H})\right), 1608(\mathrm{C}=\mathrm{C})_{\mathrm{Ar}}, 1525\left(-\mathrm{NO}_{2}\right)_{\text {asym }}, 1349\left(-\mathrm{NO}_{2}\right)_{\text {sym }}, 1124(-$ $\left.(\mathrm{O}=\mathrm{C})-\mathrm{OCH}_{3}\right)$. HRMS $\left(\mathrm{FAB}^{+}\right)$: $(\mathrm{M}+1)^{+}$found 998.231874. $\mathrm{C}_{45} \mathrm{H}_{40} \mathrm{~N}_{7} \mathrm{O}_{20}$ calculated 998.232812. m. p.: $83-85^{\circ} \mathrm{C}$.

${ }^{1}$ H-NMR titrations experiments. NMR titrations were carried out placing in a NMR tube the ligand $\left(1.1 \times 10^{-2} \mathrm{M}\right)$ in the appropriate deuterated solvent $\left(0.6 \mathrm{ml}\right.$ of DMSO or $\left.\mathrm{CH}_{3} \mathrm{CN}\right)$ and recording its ${ }^{1} \mathrm{H}-\mathrm{NMR}$ spectrum. After addition of the corresponding carboxylic salt $(0.358 \mathrm{M})$ in aliquots of 0.2 equivalents each time, ${ }^{1} \mathrm{H}-\mathrm{NMR}$ spectrum was recorded. This process was repeated until 3.0 equivalents of carboxylic salt were added in respect to the ligand. In order to determine the complexing constants, the SPECFIT programme was used. ${ }^{11}$

\section{Acknowledgements}

We acknowledge the support from the Dirección General de Ciencia y Tecnología, project CTQ 2005-07562-C04-01 and from the Generalitat Valenciana project GVACOMP2006-112, and S.P. thanks the Spanish Government for a predoctoral fellowship. Finally, SCSIE (Universidad de Valencia) is gratefully acknowledged for all the equipment employed.

\section{Supporting Information Available}

Aromatic zone of the ${ }^{1} \mathrm{H}$ NMR spectrum of ligand 1 + TBAI (in d6-DMSO). Aromatic zone of the ${ }^{1} \mathrm{H}$ NMR spectrum of ligand $\mathbf{1}+\mathrm{TBAAcO}$ (in $\mathrm{DC}_{3} \mathrm{CN}$ ). Aromatic zone of the ${ }^{1} \mathrm{H} \mathrm{NMR}$ spectrum of ligand 1 (in d6-DMSO). Aromatic zone of the ${ }^{1} \mathrm{H}$ NMR spectrum of ligand $1+$ TBAbenzoate (in $\mathrm{DC}_{3} \mathrm{CN}$ ). Aromatic zone of the ${ }^{1} \mathrm{H}$ NMR spectrum of ligand $1+$ TBA 4methoxybenzoate (in d6-DMSO). Aromatic zone of the ${ }^{1} \mathrm{H}$ NMR spectrum of ligand 1 + TBA 4nitrobenzoate (in d6-DMSO). Stoichiometry for the complex formed between ligand 1 and tetrabutylammonium bromide in $\mathrm{CD}_{3} \mathrm{CN}$ (determined by molar ratio titration using ${ }^{1} \mathrm{H} \mathrm{NMR}$ ). Stoichiometry for the complex formed between ligand $\mathbf{1}$ and tetrabutylammonium 4nitrobenzoate in d6-DMSO (determined by both molar ratio titration and Job plot using ${ }^{1} \mathrm{H}$ NMR). Stoichiometry for the complex formed between ligand $\mathbf{1}$ and tetrabutylammonium 4methoxybenzoate in d6-DMSO (determined by both molar ratio titration and Job plot using ${ }^{1} \mathrm{H}$ NMR). Stoichiometry for the complex formed between ligand 1 and tetrabutylammonium 4acetate in $\mathrm{CD}_{3} \mathrm{CN}$ (determined by molar ratio titration using ${ }^{1} \mathrm{H} \mathrm{NMR}$ ). 


\section{References}

1. (a) Martínez-Máñez, R.; Sancenón, F. Chem. Rev. 2003, 103, 4419. (b) Suksai, C.; Tuntulani, T. Chem. Soc. Rev. 2003, 32, 192. (c) Sessler, J. L.; Camiolo, S.; Gale, P. A. Coord. Chem. Rev. 2003, 240, 17.

2. Bondy, C. R.; Loeb, S. J. Coord. Chem. Rev. 2003, 240, 77.

3. (a) Nie, L.; Lie, Z.; Han, J.; Zhang, X.; Yang, R.; Liu, W.-X.; Wu, F.-Y.; Xie, J.-W.; Zhai Y.-Z.; Jiang, Y.-B. J. Org. Chem. 2004, 69, 6449. (b) Evans, L. S.; Gale, P. A.; Lighat, M. E.; Quesada, R. Chem. Commun. 2006, 965.

4. (a) Costero, A. M.; Bañuls, M. J.; Aurell, M. J. Tetrahedron 2004, 60, 9471. (b) Costero, A. M.; Bañuls, M. J.; Aurell, M. J.; Ochando, L. E.; Domenech, A. Tetrahedron 2005, 61, 10309.

5. Costero, A. M.; Sanchis, J.; Peransi, S.; Gil, S.; Sanz, V.; Domenech, A. Tetrahedron 2004, 60, 4683.

6. Kumar, S.; Hundal, M. S.; Kaur, N.; Singh, R.; Hundal, G.; Ripoll, M. M.; Aparicio, J. S. J. Org. Chem. 1996, 61, 7819.

7. (a) Peng, X.; Wu, Y.; Fan, J.; Tian, M.; Han, K. J. Org. Chem. 2005, 70, 10524. (b) Zhang, B.-G.; Xu, J.; Zhao, Y.-G.; Duan, C.-Y.; Cao, X.; Meng, Q.-J. Chem. Soc., Dalton Trans. 2006, 1271.

8. Amendola, V.; Esteban-Gómez, D.; Fabbrizzi, L.; Licchelli, M. Acc. Chem. Res. 2006, 39, 343.

9. (a) Neumann, T.; Dienes, Y.; Baumgartner, T. Org. Lett. 2006, 8, 495. (b) Badr, I. H. A.; Meyerhoff, M. E. J. Am. Chem. Soc. 2005, 127, 5318. (c) Lin, Z.; Zhao, Y.; Duan, C.; Zhang, B.; Bai, Z. J. Chem. Soc., Dalton Trans, 2006, 3678.

10. Chriswell, C. D.; Schilt, A. A. Anal. Chem. 1975, 47, 1623.

11. SPECFIT/32 ${ }^{\mathrm{TM}}$ Global Analysis System. Version 3.0 for 32-bit Windows Systems. Spectrum Associates, Marlborough, MA, USA, www.bio-logic.info/rapidkinetics/specfit.html.

12. (a) Sessler, J. L.; Andrievsky, A.; Kral, V.; Lynch, V. J. Am. Chem. Soc. 1997, 119, 9385.

(b) Fujimoto, C.; Kusunose, Y.; Maeda, H. J. Org. Chem. 2006, 71, 2389. 